\title{
To Study the Effect of Clove Oil on Physical Properties of Khadi Cotton
}

\author{
Rita Kant $^{1}$, Charu Chopra ${ }^{2}$, Nidhi Sisodia ${ }^{3}$ \\ ${ }^{1}$ Assistant Professor, Institute of Fashion Technology, Panjab University, Chandigarh \\ ${ }^{2}$ Research Scholar, Institute of Fashion Technology, Panjab University, Chandigarh \\ ${ }^{3}$ Scientific Officer, Northern India Textile Research Association, Ghaziabad
}

\begin{abstract}
The study focused on the development of bacteria resistant khadi cotton fabric by treating it with clove essential oil. In this study an attempt has been made to produce eco-friendly khadi cotton fabric which is bacteria resistant and safe for human use. Herbal extracts wereapplied to grey khadi cotton fabric in three concentrations $(1 \%, 3 \%$ \& $5 \%)$. The samples were tested for physical properties such as crease recovery, bending length, breaking strength and tearing strength of treated and untreated khadi cotton fabric.
\end{abstract}

Keywords: Eco-friendly, Essential Clove oil, Crease Recovery, Bending Length

\section{Introduction}

Clothing and textile materials are in permanent contact with human skin but they are also carriers of micro-organisms such as pathogenic bacteria, odour-generating bacteria and fungi because of the adhesion of micro-organisms on the fabric surface [Deepti G, (2007)]. These bacteria not only cause fibre damage, discolouration and stains but also lead to unpleasant odour in humans. To protect the wearer from infection from microbial attack, textiles can be given finishes with antimicrobial agents. Anti-microbial fabrics are thus developed by either binding anti-microbial agents to fabrics or by allowing the anti-microbial agents to penetrate into outer surface of fibres. The major classes of synthetics anti-microbial agents used for textiles include organometallics, triclosan, metal and their salts which are currently used by the consumers. Though these synthetic antimicrobial agents are durable yet they cause side effects as they are toxic and non- biodegradable. [Sun G and Worley SD (2005)]

Researchers are finding alternate ways to impart antimicrobial finish to textiles by using plant extracts. These finishes are durable, have wide range of activity towards micro-organisms and are non-toxic to humans. [Lewin.M.et.al. (1983)]. Plant extracts are a reservoir of pure compounds that have an enormous therapeutic potential to treat many infections. They can be used for development and production of naturally finished fabrics.Sarkar.et. al. (2003) studied the application of clove, neem, tulsi and karanja oil on cotton fabric for their anti-bacterial property.Joshi.et. al. (2009) studied the application of various natural herbal extracts, chitosan and natural dyes on textiles with emphasis on their anti-microbial behaviour. They critically analyzed their future prospects keeping in mind their durability, shelf life and anti-microbial efficiency and found that these agents can be used for imparting finish to the fabrics.Sundarajan and Rukmani (2012) studied antibacterial properties of limonene after applying it to cotton through microencapsulation by using gum acacia as wall material. It was found that limonene microcapsules were fixed to the fabric by using cross linker citric acid which formed covalent bonds with the fabric due to which the fabric retained the antibacterial property even after 5 washing cycles. Rathianamoorthy and Thilagavathi (2014) studied the application of Terminalia Chebula finish on knitted cotton structures for in vivo analysis. They found that odour formation in textiles is related to thickness and mass per square meter. The finish was applied and tests were conducted to analyze the intensity of odour. It was concluded that higher percentage of anti-bacterial agent leads to odour reduction giving an eco-friendly way of finishing textile material.

It is seen that fabric is the most receptive surface for microbial growth and is in continuous contact with human skin. For this reason scientist and researchers are finding novel ways to solve this problem and make fabric that is bacteria and odour free. Further specialized fabric that does not allow growth of micro-organisms is useful for clothing of babiesas their skin is sensitive and more prone to bacterial infections. Such type of special fabric can be made by applying anti-odour finishes that suppress odour perception by controlling the metabolic by products of bacteria. This finish not only imparts medicinal properties but also relieves mental stress in humans by simulating sense organs.

Based on literature reviews, herbal extract clove oil was applied to khadi cotton fabric by pad-dry-cure-method.

\section{Objectives of the Study}

The main objective of the present study is to make an ecofriendly, functionally protective eco-friendly fabric.

- To study the behavioral properties of khadi cotton fabric.

- To apply anti-odor finish on this fabric.

- To study the effect of this finish on behavioral properties of this fabric.

\section{Significance of the stud}

Babies, people older in age and patients in general are more prone to infections because of their low immunity and delicate skin. The developed fabric can be used safely for clothing and linen for this sensitive population. This material

\section{Volume 6 Issue 12, December 2017}




\title{
International Journal of Science and Research (IJSR) \\ ISSN (Online): 2319-7064
}

Index Copernicus Value (2016): 79.57 | Impact Factor (2015): 6.391

would not only fight against germs and microorganisms it would at the same time be environment friendly and sustainable in several ways.

\section{Methodology}

To achieve the above purpose clove oil was applied on khadi cotton fabric by pad-dry-cure method and the changes in properties of the fabric were studied. Clove oil was taken with $7 \%$ of citric acid as crosslinker. Fabric was dipped in the solution for 30 minutes at room temperature, pressure: 1.5 bar, M.L.R 1:40 followed by padding. The samples were dried at $80^{\circ} \mathrm{C}$ for 4 minutes and cured at $140^{\circ} \mathrm{C}$ for 2 minutes. Clove oil was selected due to its anti-odour and antibacterial properties. Eugenol is the main constituent of clove oil which is extracted from the bud of clove plant Syzigiumaromaticum through steam distillation. It has the property of repelling various microorganisms. The samples were coded according to concentrations of the solution and then they were subjected to padding and functional tests (Tearing Strength, Tensile Strength, Bending Length, Crease Recovery) were performed. The finish was applied in three concentrationsi.e. $\mathrm{P}_{1^{-}} 1 \%, \mathrm{P}_{3}-3 \%$ and $\mathrm{P}_{5^{-}} 5 \%$ of clove oil and $\mathrm{P}_{\mathrm{c}}-$ Control sample. Citric acid was used as crosslinking agent for the process.

\section{Results and Discussion}

The results show the changes in the fabric properties after application of anti-odour finish.

- Tensile Strength-It is the term used to measure the fabric strength in $\mathrm{kg}$ per square $\mathrm{mm}$ or Newtons per square meter. It is determined as the force required to break a fabric in cross-sectional mass equivalent to one unit of the measure used.The tensile strength showed reduction with increase in concentration of finish. The tensile strength ranged from $364.11 \mathrm{~N}$ to $325.211 \mathrm{~N}$ in weft and $403.004 \mathrm{~N}$ to $326.95 \mathrm{~N}$ in warp for $1 \%-5 \%$ concentration of finish respectively. It can be said that application of finish in higher concentrations reduces the tensile strength as compared to lower concentrations.

Table 1: Tensile strength of finished cotton samples

\begin{tabular}{|c|c|c|c|}
\hline $\begin{array}{c}\text { Sample } \\
\text { Code }\end{array}$ & $\begin{array}{c}\text { Concentration } \\
\text { of Clove Oil (\%) }\end{array}$ & $\begin{array}{c}\text { Load } \\
\text { Warp }\end{array}$ & $\begin{array}{c}\text { (NEWTON) } \\
\text { WEFT }\end{array}$ \\
\hline $\mathrm{P}_{\mathrm{c}}$ & 0 & 423.5 & 394.5 \\
\hline $\mathrm{P}_{1}$ & $1 \%$ & 403.004 & 364.537 \\
\hline $\mathrm{P}_{3}$ & $3 \%$ & 378.4 & 340.5 \\
\hline $\mathrm{P}_{5}$ & $5 \%$ & 326.95 & 325.211 \\
\hline
\end{tabular}

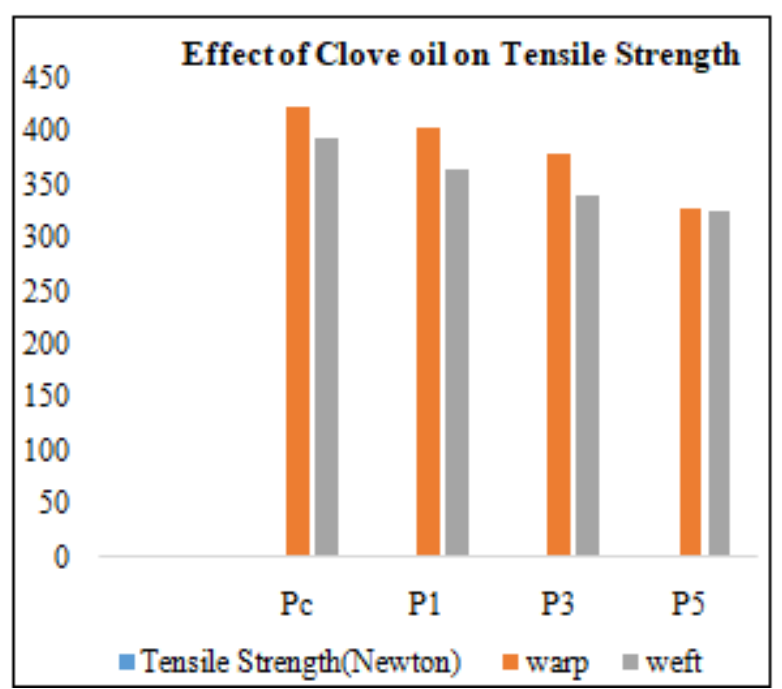

Chart 1: Showing Effect of Clove oil on Tensile Strength

- Tearing Strength-The tearing strength also showed a reduction of $10-20 \%$ with increase in concentration of finish. Initially, when the finish was applied in low concentration (1\%) the requirement of load was $533 \mathrm{gm}$ but it reduced to $487.5 \mathrm{gm}$ in warp and $525.5 \mathrm{gm}$ to $510.5 \mathrm{gm}$ in weft with increase in concentration (5\%). It can be said that application of finish in higher concentrations reduces the tearing strength as compared to lower concentrations.

Table 2: Tearing strength of finished cotton samples

\begin{tabular}{|c|c|c|c|}
\hline $\begin{array}{c}\text { Sample } \\
\text { Code }\end{array}$ & $\begin{array}{c}\text { Concentration Of } \\
\text { Clove Oil (\%) }\end{array}$ & $\begin{array}{c}\text { Load } \\
\text { Warp }\end{array}$ & $\begin{array}{c}\text { (Gram) } \\
\text { WEFT }\end{array}$ \\
\hline $\mathrm{P}_{\mathrm{c}}$ & 0 & 590 & 560.5 \\
\hline $\mathrm{P}_{1}$ & $1 \%$ & 533 & 525.5 \\
\hline $\mathrm{P}_{3}$ & $3 \%$ & 510 & 500 \\
\hline $\mathrm{P}_{5}$ & $5 \%$ & 487.5 & 510.5 \\
\hline
\end{tabular}

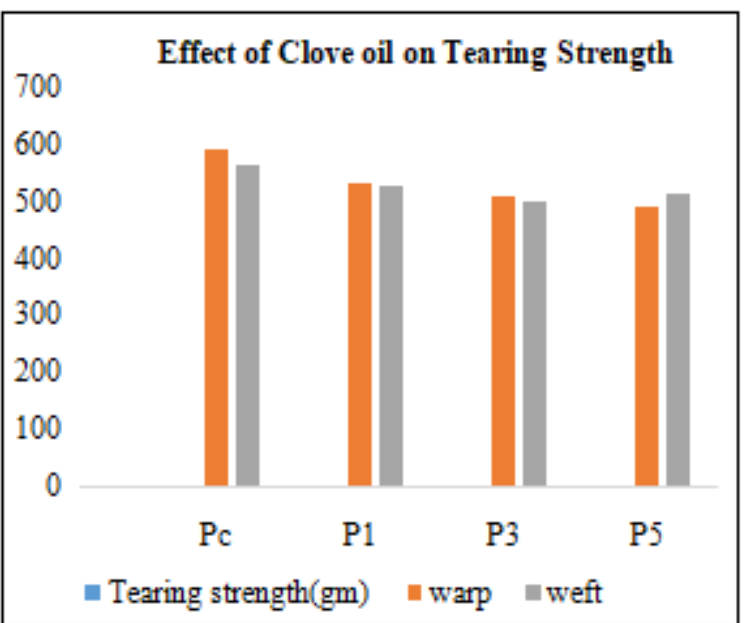

Chart 2: Showing Effect of Clove Oil on Tearing Strength

- Bending Length-Bending length gives thefabric property of comfort in wearing. The bending length decreases with high concentration i.e. $2.27 \mathrm{~cm}$ to $1.65 \mathrm{~cm}$ in warp and $2.02 \mathrm{~cm}$ to $1.55 \mathrm{~cm}$ in weft. It can be concluded that application of finish in low concentration with cross linker is recommended.

Table 3: Bending Length of finished cotton samples

\section{Volume 6 Issue 12, December 2017}

\author{
www.ijsr.net
}


International Journal of Science and Research (IJSR)

ISSN (Online): 2319-7064

Index Copernicus Value (2016): 79.57 | Impact Factor (2015): 6.391

\begin{tabular}{|c|c|c|c|}
\hline $\begin{array}{c}\text { Sample } \\
\text { Code }\end{array}$ & $\begin{array}{c}\text { Concentration } \\
\text { of Clove Oil (\%) }\end{array}$ & $\begin{array}{c}\text { Bending } \\
\text { Warp }\end{array}$ & $\begin{array}{c}\text { Length }(\mathrm{cm}) \\
\text { WEFT }\end{array}$ \\
\hline $\mathrm{P}_{\mathrm{c}}$ & 0 & 2.27 & 2.025 \\
\hline $\mathrm{P}_{1}$ & $1 \%$ & 2.05 & 1.74 \\
\hline $\mathrm{P}_{3}$ & $3 \%$ & 1.75 & 1.65 \\
\hline $\mathrm{P}_{5}$ & $5 \%$ & 1.65 & 1.55 \\
\hline
\end{tabular}

\subsection{Effect of Clove Oil on Bending length}

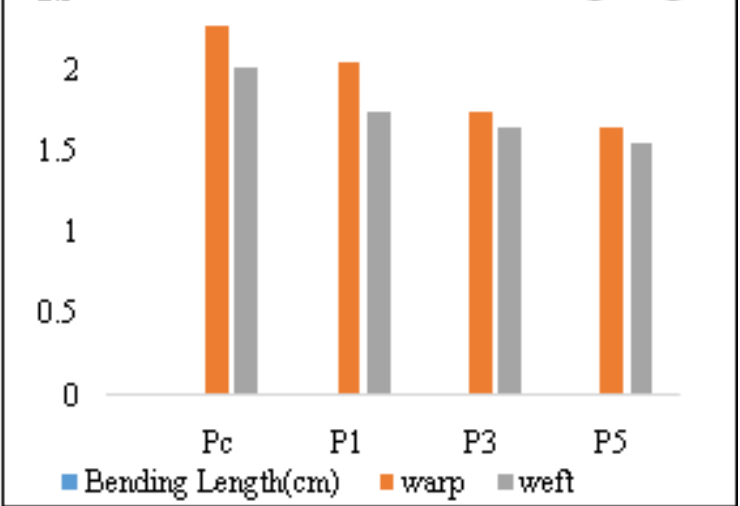

Chart 3: Showing Effect of Clove Oil on Bending Length

- Crease Recovery Angle-The ability of a fabric to retain its crease where wanted and to recover from wrinkling is an important property especially in case of apparel fabrics. The crease recovery angle increases with treatment. Initially the angle measured is 101 degrees but with increase in concentration of finish with citric acid as cross linker it increased to 103 degrees in warp and from 89 to 92 degrees in weft. It can be concluded that usage of finish can be done at low concentrations.

Table 4: Crease recovery angle of finished cotton samples

\begin{tabular}{|c|c|c|c|}
\hline Sample Code & $\begin{array}{c}\text { Concentration of } \\
\text { Clove Oil (\%) }\end{array}$ & Angle Warp & $\begin{array}{c}\text { (Degrees) } \\
\text { Weft }\end{array}$ \\
\hline $\mathrm{P}_{\mathrm{c}}$ & 0 & 101 & 89 \\
\hline $\mathrm{P}_{1}$ & $1 \%$ & 101.5 & 90 \\
\hline $\mathrm{P}_{3}$ & $3 \%$ & 102 & 91 \\
\hline $\mathrm{P}_{5}$ & $5 \%$ & 103 & 92 \\
\hline
\end{tabular}

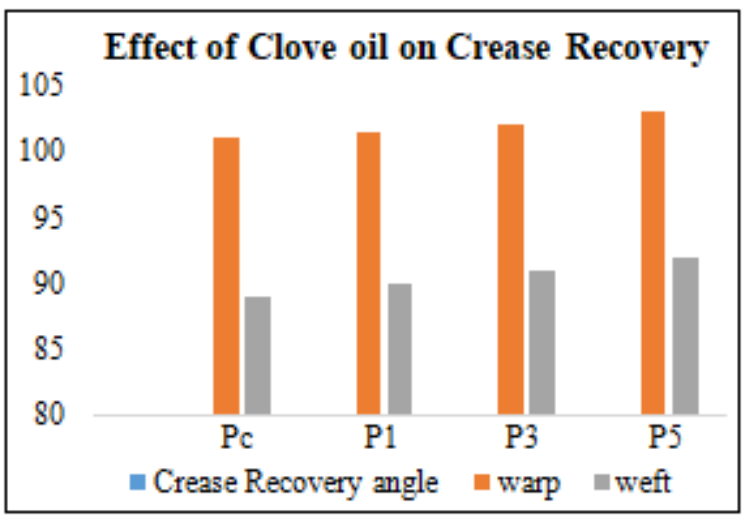

Chart 4: Showing Effect of Clove Oil on Crease Recovery

\section{Conclusion}

Following the above methodology, the results from study showed that application of finish in higher concentrations makes the fabric low in tensile and tearing strength but the use of cross linking agent decreases the stiffness and increases crease recovery angle thus making the fabric wrinkle free.Based on the findings of this experimental study it can be said that application of Clove Oil finish in low concentration with cross linker helpsdevelop a textile that has desired functional utility.

\section{References}

[1] Chandrasekaran K, Anbumani N \&PriyalVaidehi V, (2015). Analysis of eco-friendly medicinal herb extracts and essential oil applications on textile products for healthcare applications. Indian Journal of Traditional Knowledge, Vol. 14(3),pp 481-487.

[2] Deepti G, (2007), Antimicrobial Treatment for Textiles, Indian J Fibre Text Res, Vol32, pp 254-263.

[3] Essential oil-Uses and Benefits. Retrieved October 11, 2015 from www.aromaweb.com/essentialoils/default.

[4] Geethadevi R and Maheshwari V, (2015), Long-Lasting UV protection and mosquito repellent finish on bamboo/tencel blended fabric with microencapsulated essential oil, Indian Journal of Fibre and Textile Research, Vol. 40, (6), pp 175-179.

[5] Ghosh Subhas and Chipot Natalie, (2015), Embedding aromatherapy essential oils into textile fabric using Beta- Cyclodextrin inclusion compound, Indian Journal of Fibre and Textile Research, Vol. 40, (6), pp 140-143.

[6] JaswalPriya, AgyaPreet, Simran and GoelGarima, (2017), Antimicrobial activity of herbal treated cotton fabric, International Journal of Engineering and Technology (IRJET), Vol 4,Issue 8,pp 39-43.

[7] Joshi M, Wazed Ali S. Purwar R \&Rajendran S, (2009), Ecofriendly antimicrobial finishing of textiles using bioactive agents based on natural products, Indian $J$ Fibre Text Res, Vol 34 (9), pp 295-304.

[8] Lewin.M. and Sello S.B.,Eds,Vigo T.L. (1983), Protection of Textiles from Biological Attack, "Hand book of fiber Science and Technology, Volume II, Chemical Processing of Fibers and Fabrics, Functional Finishes, Part A". Marcel Dekker, Inc.NY,pp-367-426

[9] Rathinamoorthy R and Thilagavathi G, (2014), Effect of Anti-Microbial Finish on Odor Control Properties of Apparel Fabric, Journal of Textile and Apparel, Technology and Management, Vol. 9 Issue 1, pp 1-15

[10] Sarkar R K, Purushottam D \& Chauhan P D, (2003), Bacteria-resist finish on cotton fabrics using natural herbal extracts, Indian J Fibre Text Res, Vol 28 (9), pp 322-331.

[11] Sun G and Worley SD (2005). Chemistry of Durable and Regenarable Biocidal Textiles. Journal of Chemical Education, Vol. 82(1),pp 60-64

[12] Sundrarajan M and Rukmani A, (2013), Durable AntiBacterial finishing on cotton by impregnation of Limonene Microcapsules, American Scientific Publishers, Advanced chemistry letters, Vol 1, pp 4043.

\section{Volume 6 Issue 12, December 2017}

